\title{
Pomiędzy Lwą a Stwigą. Stanisław Kulczyński i jego projekt utworzenia poleskiego parku natury z I932 roku
}

\author{
Between the Lwa and Stwiga Rivers. Stanisław \\ Kulczyński and His 1932 Plan for a Grand Natural \\ Park in Pripet Marshes
}

In 1928, when the Bureau for the Project of Amelioration of Polesie (a large marshy area in the eastern part of interwar Poland) began its field studies, environmental concerns were low on the list of its priorities. A year later, this brought the Bureau into serious conflict with the State Council for Nature Protection. When both institutions eventually came to terms with their contradictory ambitions and vaguely-defined competences to enter into substantial cooperation, the idea of reserving a large area of marshlands as a natural park came into being. In 1932, Stanisław Kulczyński, a botanist leading the Bureau's peat bog research team and also a Council member, proposed protecting an area of roughly 100,000 hectares between the Lwa and Stwiga rivers. The future park would encompass most types of landscape typical of Polesie and, fortunately, most of its swamps, forests, dunes, and peat bogs were barely touched by human activity. The hydrogeological feature of the selected area safeguarded its immunity to the potential consequences of the amelioration works, if such were undertaken in any of the surrounding areas. This paper explores how the location and extent of the protection of the park were negotiated within the entangled networks of social, economic, and political agendas of national policy in inter-war Poland. The efforts to coordinate the pro-nature policy in Polesie with similar actions undertaken by the Soviets beyond the nearby border are also covered.

Keywords: nature protection, environment, peat bogs, Pripet marshes Słowa kluczowe: ochrona przyrody, środowisko, torfy, Polesie

W trwającej przez niemal całe dwudziestolecie międzywojenne debacie wokół przyszłości Polesia ważną rolę zajmowała sprawa uchronienia przynajmniej niewielkich fragmentów tamtejszego krajobrazu przed skutkami planowanych na tym obszarze robót meliora- 
cyjnych. Początkowo kierownictwo Biura Projektu Melioracji Polesia (BPMP), powołanego w 1928 r. z zadaniem opracowania projektu technicznego odwodnienia 1,5 miliona hektarów poleskich bagien, nie poświęcało kwestiom środowiskowym wiele uwagi, przedkładając ponad nie interes ekonomiczny, a także społeczny i polityczny planowanej inwestycji. Sytuacja zmieniła się na początku 1929 r., gdy Państwowa Rada Ochrony Przyrody (PROP) wystąpiła z postulatem wyłączenia z projektu najcenniejszych przyrodniczo terenów i utworzenia na nich parku narodowego. Pomiędzy kierownikami obu instytucji, Józefem Próchnikiem (1873-1951) jako dyrektorem Biura, a Władysławem Szaferem (1886-1970) jako przewodniczącym Rady, doszło wówczas do ostrego konfliktu. Sednem sporu było nieprecyzyjne określenie kompetencji obu instytucji, ale niemałą rolę odegrały też nieporozumienia oraz zwykłe, ludzkie ambicje obu indywidualności'. Mimo początkowych tarć, podjęli oni współpracę, która zaowocowała przyjęciem planu utworzenia na Polesiu dużego, obejmującego około 100 tysięcy hektarów rezerwatu przyrody obejmującego większość charakterystycznych elementów tamtejszego krajobrazu.

Kluczową rolę w określeniu programu ochrony przyrody na Polesiu odegrał Stanisław Kulczyński (1895-1975), profesor botaniki z Uniwersytetu Jana Kazimierza we Lwowie. Był członkiem PROP, w której blisko współpracował z Szaferem, również botanikiem i profesorem Uniwersytetu Jagiellońskiego, a prywatnie - swoim bliskim przyjacielem. Jako specjalista $w$ dziedzinie badań florystycznych Kulczyński został zaangażowany w prace badawcze BPMP, stając się tym samym mimowolnym łącznikiem pomiędzy obydwoma instytucjami i ich kierownikami. Kulczyński wskazał w terenie lokalizację przyszłego rezerwatu, czy też - jak go nazywał - poleskiego parku natury i zdefiniował jego główne przedmioty ochrony. W rozumieniu współczesnej klasyfikacji miał to być obszar II kategorii ochrony, czyli park narodowy ${ }^{2}$. Ostatecznie jednak w okresie międzywojennym do jego powołania nie doszło.

W artykule podjęto próbę rekonstrukcji procesu definiowania przedmiotu ochrony projektowanego parku. Zagadnienie to nie zostało jak dotąd omówione ani w piśmiennictwie polskim poświęconym międzywojennym dziejom polskich ziem wschodnich, ani w literaturze z zakresu historii ochrony środowiska w Polsce. W pracy szczegółowo przeanalizowano również argumentację, na jakiej oparł się Kulczyński wskazując międzyrzecze Lwy i Stwigi jako lokalizację parku. W analizie tej posłużono się przede wszystkim raportem, jaki złożył na ręce Szafera najprawdopodobniej na wiosnę 1932 r. Raport ten nie ukazał się nigdy drukiem, choć krótkie jego fragmenty znalazły się w artykule promującym ideę powołania poleskiego parku natury opublikowanym przez Szafera rok później $^{3}$. W niniejszej pracy omówiono ponadto próby nawiązania współpracy ze Związkiem Radzieckim w sprawie koordynacji działań ochronnych w rejonie przygranicznym. Praca powstała w oparciu o niepublikowane dotychczas archiwalia dokumentujące działalność PROP, przechowywane obecnie w Archiwum Nauki Polskiej Akademii Nauk i Polskiej Akademii Umiejętności w Krakowie.

1 Kulisy tego sporu zostały szczegółowo wyjaśnione w: S. Łotysz, Władysław Szafer i Józef Próchnik w debacie o przyszłości poleskiej przyrody, „Analecta: Studia i Materiały z Dziejów Nauki” 2019, nr 1, s. 189-211.

2 Zdaniem Szafera obie nazwy były tożsame. Zob. W. Szafer, Uwagi o celach i organizacji badań naukowych w polskich parkach natury, "Ochrona Przyrody" 1922, z. 3, s. 10.

3 W. Szafer, Ochrona przyrody na Polesiu, [w:] Postępy prac przy Melioracji Polesia, Brześć nad Bugiem 1933, s. $133-139$. 
W lutym 1928 r. jako samodzielna jednostka w strukturach ministerstwa robót publicznych, powołane zostało Biuro Projektu Melioracji Polesia. Jej kierownictwo powierzono Józefowi Próchnikowi (1873-1951), pierwszemu ministrowi robót publicznych w odrodzonej Rzeczypospolitej; funkcję tę piastował zaledwie przez kilka miesięcy w 1919 r. Próchnik był doświadczonym inżynierem z wieloletnią praktyką w administracji wodnej oraz terenowych dyrekcjach robót publicznych na obszarze Małopolski Wschodniej i Wołynia. Na Polesie został przeniesiony dopiero na rok przed utworzeniem Biura, najwyraźniej po to, by przygotować jego struktury.

Zadanie, jakie przed nim postawił minister robót publicznych, Jędrzej Moraczewski, było niezwykle trudne i złożone. Prac projektowych nie można było podjąć bez przeprowadzenia badań wstępnych, przede wszystkim geologicznych, hydrologicznych, glebowych oraz ekonomicznych. Brakowało nawet wiarygodnych map, bez których w teren nie mogły wyruszyć żadne zespoły badawcze. Próchnik przystąpił energicznie do pracy, organizując w pierwszej połowie 1928 r. trzy konferencje, których celem było wyłonienie zespołów badawczych i podział pomiędzy nimi zadań w poszczególnych dyscyplinach. Oprócz wspomnianego Kulczyńskiego, w prace te zaangażowano wielu wybitnych specjalistów w różnych dziedzinach, by wymienić geologa Mieczysława Limanowskiego (18761948), geografa Stanisława Pawłowskiego (1882-1940), hydrologa Romualda Rosłońskiego (1880-1956), hydrotechnika Jana Łopuszańskiego (1875-1936), gleboznawcę Tadeusza Mieczyńskiego (1888-1947) czy botanika Dezyderego Szymkiewicza (1885-1948).

Próchnik, jako „dziecko wsi polskiej”, uważał się za wielkiego miłośnika przyrody, jednak w programie badawczym Biura nie uwzględnił analizy skutków oddziaływania inwestycji na środowisko naturalne Polesia4. Powołał wprawdzie tzw. grupę ekologiczną, której kierownictwo powierzył Szymkiewiczowi, ale zajmowała się ona głównie oceną żyzności gleby i warunkami wzrostu roślin uprawnych. W domku wegetacyjnym wybudowanym na torfowisku Czemerne prowadzono uprawy wazonowe na podłożu z różnych typów torfów, przywiezionych z innych rejonów Polesia 5 . Starano się określić, jaki wpływ na wzrost roślin mają takie czynniki jak: nasłonecznienie, parowanie, promieniowanie, zawartość dwutlenku węgla w powietrzu, a także odczyn pH gleby oraz jej temperatura i wilgotność ${ }^{6}$. Na podstawie wyników tych badań Szymkiewicz dowodził między innymi, że w wyniku prac melioracyjnych Polesiu nie grozi przesuszenie ${ }^{7}$, przed czym przestrzegali krytycy pośpiesznego przystąpienia do robót w terenie. Obawy te, wyrażone przez uczestników X Zjazdu PROP w styczniu 1929 r., stały się głównym powodem wspomnianego konfliktu pomiędzy Szaferem a Próchnikiem, a szerzej - pomiędzy ekologicznym a technologicznym podejściem do kwestii melioracji Polesia. Można w tym miejscu postawić tezę,

4 Archiwum Nauki Polskiej Akademii Nauk i Polskiej Akademii Umiejętności [AN], Zesp. Państwowej Rady Ochrony Przyrody, sygn. 48 Próchnik do Szafera, 9.03.1929 r.

5 D. Szymkiewicz i B. Świętochowski, Oznaczanie potrzeb nawozowych torfów poleskich metodą wazonową, [w:] Postępy prac przy melioracji Polesia, Brześć nad Bugiem 1933, s. 123-127.

6 D. Szymkiewicz, Ilościowa charakterystyka sprawności gospodarki wodnej u roślin, [w:] Postępy prac przy melioracji Polesia, Brześć nad Bugiem 1933, s. 113-116.

7 Idem., Uwagi w sprawie rzekomo grożącego przesunięcia Polesia, [w:] Postępy prac przy melioracji Polesia, Brześć nad Bugiem 1933, s. 117-121. 
że odrzucając tak kategorycznie pogląd o niebezpieczeństwie przesuszenia, Szymkiewicz zajął w tym sporze stanowisko przeciwne do tego, jakiego bronił Szafer i większość członków Rady. A to właśnie - jak na ironię - Szafer wskazał go jako właściwą osobę, aby podczas konferencji organizowanej przez BPMP zaprezentować ideę utworzenia na Polesiu „rezerwatu przyrodniczego"8.

Nie mogąc polegać w tej sprawie na Szymkiewiczu, Szafer zwrócił się do Kulczyńskiego, swojego wieloletniego przyjaciela, a zarazem jedynego członka PROP działającego w ramach zespołów badawczych powołanych przez Biuro. Kulczyński kierował grupą florystyczno-torfową, której zadaniem była ocena wartości użytkowej torfowisk, ze szczególnym naciskiem na ich przydatność dla rolnictwa. Miał ponadto „przewidzieć i uzasadnić” jak zachowają się bagna oraz sąsiadujące z nimi tereny piaszczyste po przeprowadzeniu robót odwadniających ${ }^{9}$. Jak się później okazało, wyniki jego prac miały kluczowe znaczenie dla wyznaczenia lokalizacji przyszłego parku natury.

W trwającym kilka tygodni sporze pomiędzy Szaferem a Próchnikiem, Kulczyński zachowywał neutralne stanowisko. Nic więc dziwnego, że gdy po opadnięciu emocji szefowie obu instytucji zaczęli planować przyszłą współpracę, Kulczyński stał się ich wspólnym autorytetem: Próchnik obiecywał konsultować się z nim w sprawach przyrodniczych ${ }^{10}$, a Szafer proponował go na przewodniczącego Komisji Biologicznej, o ile ministerstwo robót publicznych zgodziłoby się powołać takie ciało, na wzór działającej przy Biurze niemal od początku, Poleskiej Komisji Geologicznej pod kierownictwem Limanowskiego ${ }^{11}$. Do powołania takiej komisji ostatecznie nie doszło, ale od tego czasu datuje się okres bliskiej współpracy pomiędzy Szaferem i Kulczyńskim z jednej, a Próchnikiem z drugiej strony.

\section{Wspólny cel}

Zbliżenie pomiędzy Radą a Biurem opierało się na dość ostentacyjnie podkreślanej zbieżności celów obu instytucji12 ${ }^{22}$. Zbieżność ta wynikała z przekonania, że największym zagrożeniem dla środowiska naturalnego Polesia była dewastacja tamtejszych lasów, o czym Próchnik informował Szafera jeszcze wiosną 1929 r. Statystyki były bezlitosne - w latach 1924-1928 wycięto tam 126800 hektarów lasów, stanowiących głównie własność prywatną. Uzyskane $w$ ten sposób grunty zostały przeznaczone na realizację reformy rolnej - likwidację serwitutów, parcelację i komasację. „Puszcza poleska padła zatem ofiarą zapotrzebowania ziemi ornej” - konstatował Kulczyński i rozwiewał ewentualne nadzieje, że ta trzebież lasów ostatecznie rozwiązała problem niedoboru gruntów rolnych na Polesiu. Przewidywał, że w niedługim czasie problem ten powróci, jeżeli nie jako rezultat wzrostu

8 Do udziału w tej konferencji Próchnik zaprosił Szafera, ten jednak wymówił się wyjazdem naukowym za granicę zaplanowanym dokładnie w tym samym terminie. Zob. AN, sygn. 48 Szafer do Próchnika, 16.06.1928 r.

9 S. Kulczyński, Rzut oka na problem bagienno-torfowy Polesia, [w:] Postęp prac przy melioracji Polesia, Brześć nad Bugiem 1933, s. 61.

10 AN, sygn. 48 Próchnik do Szafera, 9.03.1929 r.

11 AN, sygn. 48 Szafer do Próchnika, 20.03.1929 r.

12 Również interpersonalne relacje na linii Szafer-Próchnik układały się bardzo poprawnie, choć o jakiejś szczególnej sympatii raczej nie było mowy. O zaproszeniu dyrektora BPMP na kolejne, doroczne posiedzenie PROP tak pisał do Kulczyńskiego: „Próchnikowi posłałem zaproszenie na zjazd. Jeżeli Ci zależy na jego przyjeździe, to jeszcze sam ze swej strony napisz do niego list". AN, sygn. 17 Szafer do Kulczyńskiego, 2.01.1930 r. 
liczby ludności, „to jako następstwo deterioracji wydartych dzisiaj lasom ziem ornych, które w mniejszym lub większym stopniu padną ofiarą wydm"13. Kulczyński był zdania, że „puszczę poleską uratować może jedynie skierowanie ekspansji gospodarczo-rolnej na błota i torfowiska"14.

Tę konwergencję celów Kulczyński szczególnie podkreślił występując na Zjeździe PROP w styczniu 1930 r. Oznajmił wówczas, że projekt przygotowywany przez Biuro „zasadniczo z ideą ochrony przyrody się nie sprzecza, lecz układa się po jej linii"15. Zdaniem Kulczyńskiego na Polesiu należało powołać rezerwat o znacznym obszarze. Mały park argumentował - „nie byłby zresztą rezerwatem przyrody poleskiej, która odarta z uroku przestrzeni, przestałaby być tym czym jest"16. Uważał, że park taki powinien być przynajmniej dwudziestokrotnie większy od polskich Tatr, a to oznaczałoby konieczność zajęcia nawet 6 procent powierzchni całego Polesia ${ }^{17}$. Kulczyński był świadom, że wobec poważnego niedoboru ziemi nadającej się do uprawy na Polesiu plan zajęcia tak ogromnego obszaru na potrzeby rezerwatu nie znalazłby poparcia. Dopiero „otwarcie błot poleskich dla kultury rolnej" czyniło ideę utworzenia parku w ogóle realną ${ }^{18}$.

Dokładnej lokalizacji nie mógł wtedy jeszcze wskazać, wiedział jednak dobrze, czego szukał. Podczas prowadzonych od blisko dwóch lat studiów terenowych zaobserwował, że typowy układ krajobrazu przyrodniczego Polesia „z uderzającą” prawidłowością powtarza się zarówno w dolinie Prypeci, jak i w dowolnej dolinie pobocznej ${ }^{19}$. Ten typowy układ to nadrzeczne bagno typu „pińskiego”, otoczone grząskim lasem olchowym, dalej torfowiska nizinne na wyższej terasie, a na wierzchowinie - las sosnowy poprzetykany bezodpływowymi jeziorkami i torfowiskami wyżynnymi. Całość uzupełniały piaszczyste wydmy, niekiedy porośnięte sosną. Teraz trzeba było tylko znaleźć taką „poboczną dolinę", która obejmowałaby możliwie najwięcej z typowych elementów poleskiego krajobrazu. Jej położenie i morfologia musiały ponadto gwarantować, że nawet w przypadku zmeliorowania sąsiednich terenów nie doszłoby do pogorszenia stosunków wodnych na terenie rezerwatu ${ }^{20}$.

Wskazanie najwłaściwszej lokalizacji dużego parku wymagało uzgodnienia „postulatów ochrony przyrody z postulatami technicznymi"21. Prace nad projektem melioracji trwały - w lutym 1930 r. Próchnik zaczął naciskać Szafera na podanie „konkretnych

13 S. Kulczyński, Park natury na Polesiu i jego stosunek do planu melioracji, „Ochrona Przyrody” t. 10, 1930, s. 50.

14 Ibid.

15 Ibid., s. 51.

16 lbid., s. 53.

17 Przyjmując, że Tatry w granicach Polski obejmują obszar ok. 17,5 tysiąca hektarów to dwudziestokrotność tej liczby wyniosłaby 330 tysięcy hektarów. Z kolei 6 procent z 5 milionów hektarów (na tyle Kulczyński określił powierzchnię Polesia w granicach Polski) to również około 300 tysięcy hektarów. Kulczyński nie podał tej liczby wprost, najpewniej zdając sobie sprawę z reakcji, jaką mogła by wywołać w społeczeństwie. Z czasem ograniczył swoje oczekiwania do 100 tysięcy hektarów.

18 Ibid., s. 53.

19 Ibid., s. 48.

20 Był to warunek stosunkowo łatwy do spełnienia. Już Żyliński zaobserwował, że poszczególne zlewnie rzek na Polesiu stanowią osobne systemy hydrologiczne, które mogą być odwadniane niezależnie od siebie (Zob. „Wiek” 8.04.1874). Tezę Żylińskiego potwierdziły badania prowadzone z ramienia BPMP, co stało się później podstawą zmiany polityki rządu wobec kwestii melioracji Polesia, o czym będzie mowa dalej. Znamienne, że spostrzeżenie to wykorzystywano raczej by uzasadnić możliwość prowadzenia prac etapami, a nie jako przesłankę do pozostawienia któregoś z tak naturalnie zabezpieczonych ekosystemów w stanie nienaruszonym.

21 AN, sygn. 48 Próchnik do Szafera, 6.02.1930 r. 
wniosków terytorialnych i rzeczowych"22. Przede wszystkim chodziło o weryfikację, czy nie kolidują one z ogólnym planem regulacji rzek. Szafer scedował tę prośbę na Kulczyńskiego zaznaczając, że jeśli nie byłby w stanie przedstawić konkretnych propozycji, to niech chociaż wskaże na mapie kilka większych obszarów, aby było co przedstawić Próchnikowi.

Zdecydowanie łatwiejsze do przeprowadzenia było zapewnienie ochrony osobliwości przyrodniczych, których występowanie było ograniczone do niewielkich obszarów. W latach dwudziestych i trzydziestych XX w. powstało na Polesiu kilka rezerwatów, których celem było zachowanie konkretnych siedlisk roślin lub zwierząt. Najwcześniej, bo w 1924 r., powołano dwa rezerwaty dla ochrony azalii pontyjskiej (Azalea pontica), reliktowej rośliny górskiej odkrytej na terenie Polesia Wołyńskiego, którą Szafer nazywał „najpiękniejszym oreofitem wieku trzeciorzędowego" lub wręcz „najpiękniejszą polską rośliną"23. Pierwszy rezerwat, o powierzchni 30 hektarów znajdował się w Karpiłówce, a drugi, nieco mniejszy - w Snowidowiczach. W tym samym 1924 r. założono również dwa, sąsiadujące ze sobą rezerwaty bobra nad rzeką Żegulanką w powiecie kosowskim i prużańskim, w połowie drogi pomiędzy Berezą Kartuską a Iwacewiczami. Początkowo obejmowały one łącznie 260 hektarów lasów państwowych, ale po kilku latach ochroną objęto dalsze 123 hektarów lasu prywatnego ${ }^{24}$. Z kolei w 1930 r. utworzono rezerwat łosia, tzw. Łykoszyn w nadleśnictwie Wiado, gdzie na obszarze 2417 hektarów znalazły schronienie 23 sztuki tych zwierząt. W 1934 r. zespół rezerwatów nad Żegulanką rozszerzono o siedlisko łosia, co powiększyło strefę ochroną do blisko 1160 hektarów ${ }^{25}$. Najmniejszy natomiast rezerwat poleski objął niewielką zatokę jeziora Pohost w powiecie pińskim, gdzie odkryto stanowisko kotewki mucańskiej (Trapa muzzanensis), niezwykle rzadkiej rośliny wodnej, w Europie znanej ponadto jedynie $z$ dwóch innych stanowisk ${ }^{26}$.

\section{Trudne sąsiedztwo}

Z dużym prawdopodobieństwem można było zakładać, że przyszły park natury na Polesiu zostanie wyznaczony w bezpośredniej bliskości wschodniej granicy państwa. To tam znajdowało się najwięcej terenów zabagnionych, rzadko zasiedlonych i trudno dostępnych. Można tam wciąż było znaleźć obszary - zdawałoby się - nietknięte stopą człowieka, niemal pierwotne, a zatem najcenniejsze pod względem przyrodniczym. Zwrócił na to uwagę Kulczyński podczas zjazdu PROP w styczniu 1930 r. Nadmienił wówczas, że przy poszukiwaniu najwłaściwszej lokalizacji parku być może przyjdzie się „przesunąć z projektem ku wschodowi, może nawet porozumieć z Rosją, na podobieństwo porozumienia z Czechosłowacją w sprawie ochrony Karpat"27. Scenariusz taki zaczął nabierać realnych

22 AN, sygn. 48 Szafer do Kulczyńskiego, 11.02.1930 r.

23 S. Macko, Roślinność projektowanych rezerwatów na Wołyniu, „Ochrona Przyrody” t. 17, 1937, s. 135. Ponadto, 14.03.1936, Szafer wygłosił na antenie Polskiego Radia Kraków odczyt zatytułowany Azalia pontyjska, najpiękniejsza roślina polska. Zob. Wiadomości bieżące, „Ochrona Przyrody” t. 16, 1936, s. 279.

24 W. Szafer, Rozszerzenie rezerwatu bobrowego nad Żegulanką, „Ochrona Przyrody” t. 12, 1932, s. 167.

25 Rocznik Polityczny i Gospodarczy, Warszawa 1938, s. 581.

26 W. Szafer, Ochrona przyrody na Polesiu, [w:] Postępy prac przy Melioracji Polesia, Brześć nad Bugiem 1933, s. 134.

27 S. Kulczyński, Park natury, s. 53. 
kształtów latem 1930 r., gdy okazało się, że również Sowieci planują objąć ochroną pewne obszary białoruskiego Polesia28.

Wiadomość tę Próchnik przywiózł prosto z Mińska, dokąd zawitał w drodze powrotnej z obrad II Międzynarodowego Kongresu Gleboznawczego odbywającego się w Moskwie i Leningradzie. Korzystając z wyjazdu do Związku Radzieckiego, objechał tereny, na których prowadzono melioracje rolnicze oraz odwiedził instytucje badawcze w Moskwie, Charkowie i Zaporożu. Największe jednak wrażenie wywarł na nim pobyt na sowieckiej Białorusi, gdzie zwiedził m.in. doświadczalną stację torfową koło Mińska oraz roboty melioracyjne w dolinie rzeki Oressa w białoruskiej części Polesia ${ }^{29}$. Inwestycja ta szczególnie zainteresowała Próchnika, bowiem tamtejsze warunki przyrodnicze niewiele różniły się od tych panujących po polskiej stronie granicy, a prace prowadzono na dużym obszarze i „z wielkim rozmachem”30, czyli dokładnie tak, jak sam zamierzał działać na polskim Polesiu. Już po powrocie do kraju wysłał na Białoruś swoich dwóch inżynierów, Kazimierza Cisło i Waleriana Sobolewskiego, z zadaniem dokładniejszego zapoznania się z prowadzonymi tam robotami ${ }^{31}$.

Dyrektor BPMP był optymistą co do perspektyw nawiązania współpracy z Sowietami ${ }^{32}$. Wszystko wskazywało na to, że władze centralne w Moskwie nie miały nic przeciwko robotom melioracyjnym na pograniczu i zgadzały się na powołanie w tym celu wspólnej, polsko-radzieckiej komisji33. Jego optymizm wynikał po części z tego, że wszelkie sprawy związane z melioracjami rolnymi oraz regulacjami rzek po drugiej strony granicy podlegały Ludowemu Komisariatowi Rolnictwa z siedzibą w Mińsku³4. A ponieważ z Polski do Mińska było bliżej niż do Moskwy, to w oczach Próchnika osiągnięcie porozumienia jawiło się jako stosunkowo łatwe zadanie ${ }^{35}$. Próchnik chciał jak najszybciej wysłać do Mińska i Moskwy Kulczyckiego z nadzieją, że mógłby w sprawie „onego «zapowiednika» [rosyjskiego rezerwatu przyrody] na Polesiu zasięgnąć bliżej języka"36. A jeszcze lepiej, gdyby wszystkie te sprawy udało się omówić z Rosjanami podczas specjalnej konferencji.

Pomysł takiego spotkania powziął jeszcze na jesieni 1930 r. W końcu października Próchnik poprosił MSZ o zgodę na organizację takiego spotkania, a w styczniu miał już ustalony skład polskiej delegacji. Oprócz niego, Kulczyńskiego i Szafera do Moskwy miał jechać Tadeusz Zubrzycki (1881-1937) z Centralnego Biura Hydrograficznego i Stanisław Lencewicz (1889-1944), profesor geografii z Uniwersytetu Warszawskiego ${ }^{37}$. Konferencję

Formalna decyzja w sprawie powołania parku natury na białoruskim Polesiu zapadła dopiero w 1933 r. podczas I Wszechzwiązkowego Zjazdu Ochrony Przyrody, ale nie przyniosła żadnych praktycznych rezultatów. Zob. S.A. Tretyak, Kraj zapaviedny, [w:] J.M. Bochan i in., Bielarus praz pryzmu rehijanalnaj historyi: Prypiackaje Paliessie, Mińsk 2016, s. 328.

29 J. Próchnik, Szkice techniczne z Rosji, Ukrainy i Białorusi Sowieckiej, „Czasopismo Techniczne” t. 49, 1931, nr 13, s. 226.

30 Ibid., s. 227

31 Ibid., s. 226.

32 Część środowiska inżynierskiego oraz niektóre kręgi polityczne II RP nie podzielały tego poglądu. Zob. m.in. S. Łotysz, „Gdyby zamiast Rosji było morze..." Techniczne i polityczne aspekty odwodnienia Polesia w II Rzeczypospolitej Polskiej, [w:] Rok 1918. Odrodzona Polska i sowiecka Rosja w nowej Europie, t. 1, red. L. Zasztowt i J. Szumski, Warszawa 2019, s. 435-450.

33 AN, sygn. 48 Próchnik do Szafera, 28.10.1930 $r$.

34 Oprócz Prypeci, którą - jako rzeką żeglowaną - zarządzano z Moskwy.

35 J. Próchnik, op. cit., s. 226.

36 AN, sygn. 48 Próchnik do Szafera, 28.10.1930 $r$.

37 AN, sygn. 48 MRP do MSZ, 22.01.1931 $r$. 
wyznaczono wstępnie na marzec 1931 r., a wycieczka po radzieckiej części Polesia miała się odbyć w maju.

Na początku roku Szafer spotkał się z Kulczyńskim, aby omówić plan wyjazdu i przygotować się do spotkania. Ustalili, że zaproponują Próchnikowi uzupełnienie programu konferencji o sprawy ochrony przyrody, w tym przede wszystkim kwestię nadgranicznych rezerwatów, która - jak się okazało - mimo wcześniejszych jego zapewnień nie została uwzględniona ${ }^{38}$. Podsunęli mu ponadto pomysł, by poprosić rosyjskich gospodarzy o zorganizowanie wspólnego zwiedzania najważniejszych „profili dyluwialnych”, czyli przekrojów geologicznych osadów czwartorzędowych w okolicach Moskwy. Zależało im, by zobaczyć przede wszystkim „klasyczny i cytowany często w literaturze” profil w Lichwinie nad Oką. Prosili, aby wycieczka odbyła się w towarzystwie profesora Władimira S. Dokturowskiego (1884-1985), wybitnego rosyjskiego torfoznawcy i specjalisty w zakresie badań czwartorzędu ${ }^{39}$.

Jako że na konferencji Szafer miał reprezentować PROP, musiał uzyskać zgodę ministra Świtalskiego. Prosząc go o aprobatę i fundusze, podkreślał pilność kwestii rezerwatów pogranicznych ze względu na „żywą akcję, jaką w tym kierunku rozwija obecnie Rosja"40. Z informacji, które posiadał wynikało, że wybrano tam już wstępie kilka terenów na „duże rezerwaty poleskie", niektóre tuż przy granicy z Polską. Szafer przekonywał ministra, że wypracowanie w tej sprawie porozumienia ze wschodnim sąsiadem było wprost niezbędne, z uwagi na konieczność ochrony „wędrujących, a rzadkich gatunków zwierząt poleskich, takich jak bóbr, łoś, niedźwiedź, żbik, ryś i liczne gatunki ptaków”41.

W połowie marca było już pewne, że konferencja opóźni się. Próchnik, najwyraźniej nadal niezrażony, przyjmował to za dobrą monetę, zapewniając Szafera, iż przesunięcie terminu na maj było nawet korzystne, bowiem uczestnicy konferencji mogliby "skuteczniej oglądać i badać przyrodę na terenach Rosji sowieckiej"42. Ponieważ w końcu maja w sprawie konferencji nadal nic się nie działo, radca polskiej ambasady w Moskwie, Adam Zieleziński, spotkał się z Nikołajem J. Rajwidem, kierownikiem I Zachodniego Oddziału Komisariatu Ludowego Spraw Zagranicznych, by poprosić o wyznaczenie terminu konferencji. Rajwid zapewnił go, że w sprawie tej jest w stałym kontakcie z Komisariatem Rolnictwa i Zarządem do Spraw Melioracji i że oczekuje stamtąd odpowiedzi „z dnia na dzień".

W połowie sierpnia, a zatem po upływie kolejnych dwóch i pół miesiąca, z polskiego poselstwa w Moskwie nadeszła informacja, że prawdziwym powodem opóźnień mogła być niechęć Rosjan do przeprowadzenia wspólnego z Polakami objazdu terenowego. Według informacji przekazanej do zainteresowanych resortów przez MSZ, władze sowieckie tłumaczyły się brakiem „sił fachowych”, które w bieżącym sezonie zajęte były pracami terenowymi w innych częściach Rosji ${ }^{43}$. Według zapewnień, siły te miały być bardziej gdy po naradzie z Kulczyńskim, w końcu stycznia, Szafer poprosił Próchnika o uwzględnienie tej tematyki, ten ostatni zwrócił się do MSZ o zgodę na włączenie jej do programu. Ministerstwo zaaprobowało ten pomysł dopiero 5.03.1931 r. Zob. AN, sygn. 48 MSZ do MRP, 5.03.1931 r.

40 AN, sygn. 48 Szafer do MWRiOP, 6.02.1931 $r$.

41 lbid.

42 AN, sygn. 48 Próchnik do Szafera, 14.03.1931 r.

43 AN, sygn. 48 MSZ do MRP, 13.08.1931 r. 
dyspozycyjne w następnym roku. Zaznaczając, że wyczerpano wszelkie możliwości nakłonienia Rosjan do współpracy przy organizacji wspólnego objazdu, moskiewska placówka rekomendowała poprzestanie na organizacji samej konferencji. Ostatecznie jednak i do niej nie doszło ${ }^{44}$.

\section{Poleski park natury}

Fiasko podjętej próby skoordynowania z Rosjanami planów ochrony przyrody na Polesiu bynajmniej nie zmniejszały presji na Kulczyńskiego, by jak najszybciej wskazał lokalizację przyszłego parku natury. Prace nad projektem melioracji trwały i wyrażona przez Próchnika w lutym 1930 r. prośba o „konkretne wnioski terytorialne i rzeczowe” stawała się coraz bardziej paląca. Podstawowe znaczenie miało rozpoznanie najbardziej charakterystycznych typów krajobrazu poleskiego. Kulczyński wyróżnił ich sześć: niziny nadrzeczne pokryte szuwarami, bagna torfowe, puszcza błotna oraz sucha, a także pejzaż wydmowy i krasowy ${ }^{45}$. Uważał, że w ramach tych typów mieściły się wszystkie charakterystyczne dla Polesia „osobliwości florystyczne i faunistyczne”, które należało chronić. Problem polegał na tym, że objęcie wszystkich zidentyfikowanych typów w granicach jednego rezerwatu nie było możliwe. Krajobraz krasowy na przykład występował jedynie w południowo-zachodniej części Polesia, a moreny czołowe - na północy.

Kulczyński nie przewidywał trudności z objęciem ochroną niektórych spośród tych typów, bowiem pewnych kategorii terenu Biuro nie zamierzało w ogóle meliorować. Chodziło przede wszystkim o lasy, a konkretnie o kilka podtypów puszczy suchej (las mieszany sosnowo-dębowy na morenie ze świerkiem i bogatą florą reliktową, las sosnowy na wydmie z florą półstepową i ciemny las grabowy na glebach gliniastych) oraz o naturalne

Nie tylko Rosjanie podporządkowywali sprawy troski o środowisko naturalne bieżącej polityce. To samo można powiedzieć o postępowaniu polskiego rządu. W 1931 r., przy okazji planowanego w Warszawie III Zjazdu Botaników Słowiańskich, PROP zamierzała zorganizować spotkanie przedstawicieli organizacji ochrony przyrody z Czechosłowacji, Jugosławii, Bułgarii, oraz „ewentualnie Rosji” z zamiarem powołania Międzynarodowego Związku Ochrony Przyrody Państw Słowiańskich (zob. Sprawozdanie z 53-ego posiedzenia Wydziału Państwowej Rady Ochrony Przyrody, „Ochrona Przyrody” t. 11, 1931, s. 150). Polskie MSZ nie wyraziło wówczas zgody na zaproszenie delegata radzieckiego i ostatecznie do spotkania założycielskiego nie doszło. Rada wróciła do pomysłu dwa lata później. Tym razem planowano zaprosić Rosjan do Poznania na mający się tam odbyć we wrześniu 1933 r. XIV Zjazd Lekarzy i Przyrodników Polskich (zob. Archiwum Instytutu Hoovera [AIH], Zesp. Ministerstwa Spraw Zagranicznych, sygn. 93, k. 374 MWRiOP do MSZ, 14.03.1933 r.). MSZ nie tylko podtrzymało wówczas swój sprzeciw wobec uczestnictwa Rosjan w takim gremium, lecz także zaczęło kwestionować zasadność ujmowania zagadnień ochrony środowiska w kategoriach etnicznych czy kulturowych. Jak w wewnętrznej opinii zaznaczył Jan Gawroński, jeden z ekspertów Wydziału Wschodniego MSZ, pojęcie słowiańskości ogranicza się bowiem do przejawów ludzkiej działalności i nie obejmuje świata zwierzęcego czy roślinnego. Swoją opinię Gawroński kończył dość kąśliwie stwierdzając, że „w swej ignorancji rzeczy przyrodniczych, Wydział Wschodni jest skłonny przypuszczać, że w praktyce jedynymi niewątpliwymi okazami fauny i flory słowiańskiej, gotowymi korzystać z dobrodziejstw zamierzonej ochrony, będą członkowie zarządu" planowanej organizacji (zob. AlH, sygn. 93 Jan Gawroński, k. 368 Opinia Wydziału Wschodniego do No.P.V. 4958/3/3). W oficjalnej odmowie zaproszenia delegata Związku Radzieckiego podsekretarz stanu w MSZ, Jan Szembek, zaznaczył wprawdzie, że nie miał „zastrzeżeń przeciwko kontaktom bezpośrednim między tem państwem a Polską w kwestiach ochrony przyrody", ale zaproszenie Rosjan na zjazd uważał za niecelowe. Szembek wyjaśniał, że ZSRR nie zostało formalnie uznane przez Jugosławię i Bułgarię, które miały wziąć udział w zjeździe, a poza tym - co podkreślał - „Sowiety [...] nie uważają się wcale za państwo słowiańskie”, a nie leżało w interesie państwa polskiego by „wskrzeszać prądy słowiańskie w Rosji” (zob. AlH, sygn. 93, k. 366-366, MSZ do MWRiOP, 7.04.1933 r.).

45 AN, sygn. 48 Kulczyński do Szafera, 4.10.1932 r. 
wydmy, które nigdy nie zostały opanowane przez las. Obiekty należące do tych kategorii mogły być zatem objęte ochroną w dowolnym punkcie Polesia, co wydawało się o tyle łatwe, że większość najbardziej wartościowych lasów było własnością skarbu państwa ${ }^{46}$.

Nie zamierzano również meliorować torfowisk wyżynnych. Kulczyński uważał, że generalne wykluczenie ich z planu melioracji leżało „poniekąd i do pewnej miary w interesie samego planu”, który musiał przecież być nie tylko „technicznie poprawny, ale i rentowny" ${ }^{\prime 47}$. Otóż przy ówczesnym stanie wiedzy agrotechnicznej oraz w realiach ekonomicznych lat trzydziestych, ich zagospodarowanie na cele rolnicze uznawane było za kłopotliwe i nieopłacalne. Pogląd ten podzielał również Próchnik, który w połowie 1928 r., wspólnie z Kulczyńskim, Łopuszańskim i Szymkiewiczem odbył wyjazd studialny do Skandynawii i krajów bałtyckich, by zapoznać się z doświadczeniami tamtejszych inżynierów w zakresie melioracji torfów, również o charakterze wyżynnym ${ }^{48}$. Próby uprawy takich torfowisk podejmowano w Holandii i Niemczech, jednak uzyskiwane wyniki nie były zachęcające. Fiaskiem zakończyły się także eksperymenty prowadzone przez BPMP w majątku Temra w powiecie kobryńskim.

Nie oznaczało to, że środowisko przyrodnicze na torfowiskach wyżynnych było całkowicie wolne od zagrożeń. W niektórych rejonach Polesia podejmowano eksploatację torfu tego rodzaju na cele energetyczne zarówno do ogrzewania domów, jak i w elektrowniach. Nie można było wykluczyć wytyczenia przez takie torfowisko lub w jego pobliżu kanału spławnego, co również skutkowałoby zmianą warunków wodnych. Najbardziej zagrażała im jednak „dzika melioracja rolna uprawiana już dzisiaj na Polesiu, wynikająca z zapału melioracyjnego ludzi nie obznajomionych" z wartością rolniczą takiego terenu ${ }^{49}$. W przypadku wartego ochrony torfowiska wyżynnego można było zrezygnować z wykonania szczytowych odgałęzień pobliskich kanałów magistralnych, aby zminimalizować negatywny wpływ melioracji na położony wyżej ekosystem. Objęcie ochroną dowolnego torfowiska wyżynnego niejako przy okazji pozwalało zachować występujące zwykle na jego obrzeżach lasy mieszane na piaskach o wysokim poziomie wód gruntowych, z bogatą roślinnością bagienną w poszyciu. Była to formacja bardzo charakterystyczna dla Polesia i powszechnie występująca.

Plan melioracji nie obejmował również bezleśnych torfowisk przejściowych, ponieważ przeważnie były one suche. Tak jak torfowiska wyżynne, występowały one na międzyrzeczach, wododziałach i wysokich terasach, przez które z zasady nie projektowano kanałów magistralnych. Z kolei torfowiska nizinne mezotroficzne, występujące $w$ dolinach rzecznych, były niezbyt urodzajne i Kulczyński uważał, że wyłączenie niektórych obszarów tego typu z planu melioracji nie wiązało się z „poważniejszymi ofiarami gospodarczymi”50.

Zdecydowanie bardziej skomplikowana była sprawa ochrony eutroficznych torfowisk nizinnych, a także krajobrazu rzeki nizinnej i puszczy błotnej. Postulat ochrony obiektów z tych trzech grup Kulczyński uważał za decydujący o wyborze terenu pod zasadniczy park natury na Polesiu. Wiązała się z tym kwestia ochrony łosia i bobra w puszczy olchowej

48 J. Próchnik, Wycieczka naukowa do Estonii, Finlandii i Szwecji, „Czasopismo Techniczne” t. 47, 1929, nr 6, s. 87-93; nr 7, s. 99-105.

49 AN, sygn. 48 Kulczyński do Szafera, 4.10.1932 r.

50 Ibid. 


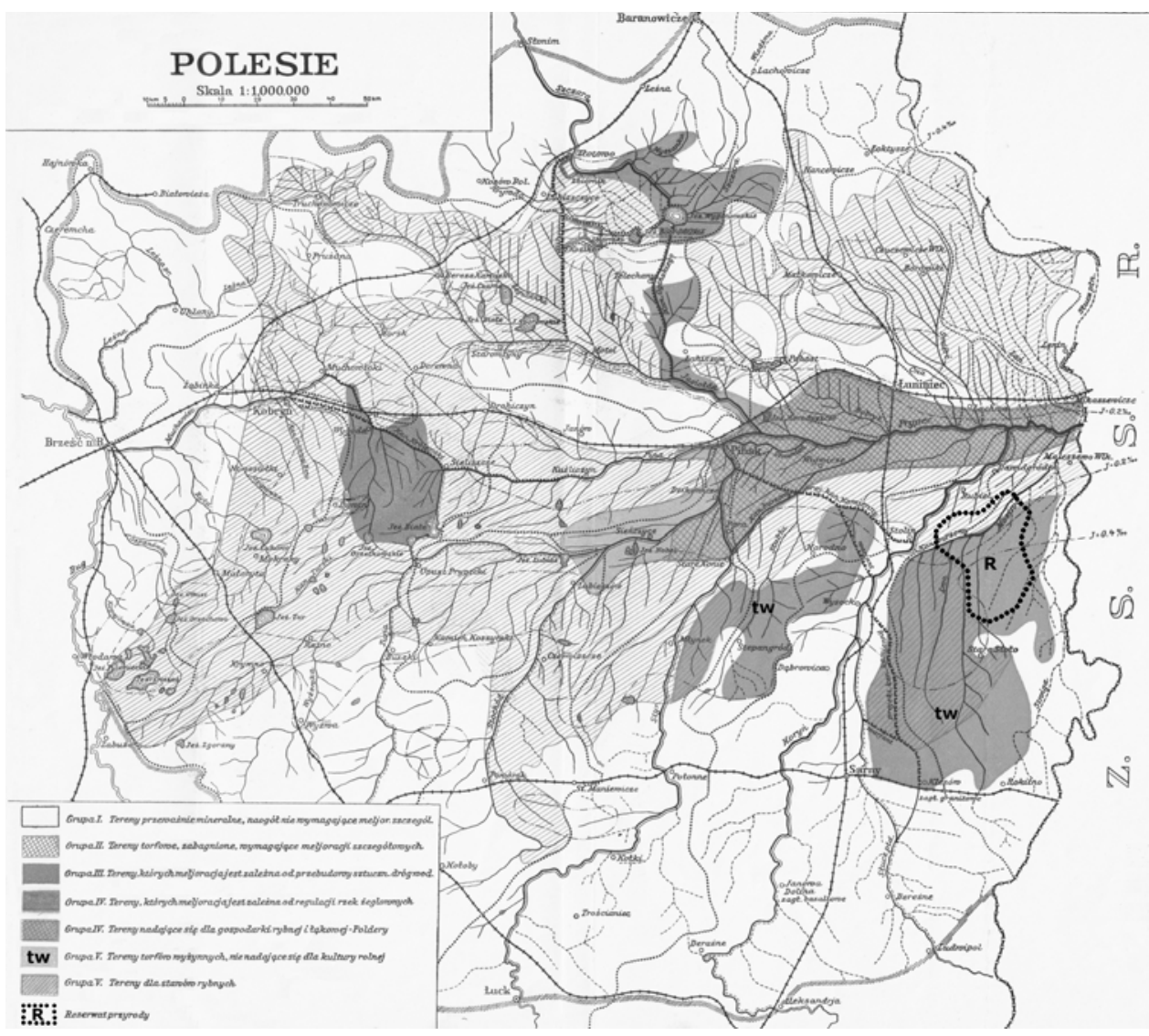

Ryc. 1. Lokalizacja projektowanego rezerwatu w relacji do planowanego zagospodarowania Polesia (opracowanie własne na podstawie: A. Konderla, Polesie. Studium krytyczne do projektu melioracji Polesia, cz. 2, "Czasopismo Techniczne” t. 51, 1933, nr 23, s. 366-367); tw - tereny torfów wyżynnych, $\mathrm{R}$ - rezerwat przyrody.

oraz ptactwa błotnego na bagnach nadrzecznych. Trudność polegała na tym, że realizacja tych postulatów w rezerwacie o niewielkiej powierzchni nie była możliwa. Ochrona nawet niewielkiego torfowiska eutroficznego wymaga zaniechania robót na znacznym obszarze, bowiem bagna takie leżą zwykle w najniższym miejscu sieci wodnej, a zatem na trasie robót technicznych. W jeszcze większym stopniu trudności te dotyczyły bagien nadrzecznych oraz puszcz olchowych, które występują na niskich terasach dużych rzek.

Kulczyński zdawał sobie sprawę, że utworzenie wielkiego parku, o powierzchni rzędu 100 tysięcy hektarów byłoby bardzo trudne na terenie nadającym się do zagospodarowania rolniczego. Wykluczało to przede wszystkim torfowiska nizinne, które po zmeliorowaniu nadawały się pod wartościowe łąki, pastwiska, a nawet pola orne. Torfowiska te były już zresztą do pewnego stopnia zagospodarowane i zamieszkane. Istniała na nich stosunkowo gęsta sieć wsi i osiedli, które w przypadku decyzji o urządzeniu rezerwatu musiały być albo wysiedlone, albo skazane na „kulturalną zagładę"51. Istniały wprawdzie 
na Polesiu wielkie rozległe torfowiska nizinne, zabagnione i bezludne, jak Hryczyn czy Dubowoje, ale były to jednolite mokradła obejmujące setki tysięcy hektarów, których częściowe wyłączenie z prac odwadniających nie było technicznie możliwe, a objęcie ochroną w całości - niecelowe z punktu widzenia przyrodniczego. Zdaniem Kulczyńskiego, taki rezerwat nie byłby trwały z uwagi na ogromny koszt realizacji i potencjalny konflikt $z$ interesem gospodarczym.

Jedynym logicznym wnioskiem, jaki się w tej sytuacji nasuwał, było urządzenie rezerwatu na torfowisku wyżynnym. Tym samym mapa torfów, nad którą od 1928 r. pracował Kulczyński, stanowiąca podstawę przygotowywanego w Biurze projektu odwodnień, stała się również kluczowym dokumentem dla wytyczenia przyszłego parku natury. Biorąc pod uwagę wszystkie uwarunkowania przyrodnicze i gospodarcze, wybór Kulczyńskiego padł na Bagna Zaolmańskie w międzyrzeczu rzek Lwa i Stwiga (Ryc. 1). To obszar leżący na południe od Prypeci, pomiędzy Horyniem, a wschodnią granicą państwa, a jego trzon stanowiły torfowiska wyżynne i przejściowe we wszystkich odmianach z wyjątkiem typu bałtyckiego. Na obrzeżach istniały obszary leśne i to kilku rodzajów - sucha puszcza sosnowa oraz błotna puszcza olchowa, „najwspanialsza na Polesiu”52. Na południowych terasach Lwy zachowały się krajobrazy wydmowe o pierwotnej florze, a w północnej części obszaru występował krajobraz nadrzeczny przypominający bagna typu pińskiego. Wytypowany obszar obejmował około 100 tysięcy hektarów ${ }^{53}$.

Zdaniem Kulczyńskiego splot zewnętrznych czynników gwarantował niezmienność tamtejszych stosunków hydrologicznych na lata, co pozwalało uznać ten teren za najbardziej stabilny pod tym względem na całym Polesiu. Kulczyński zakładał, że w przewidywalnej przyszłości nie dojdzie do prac regulacyjnych po wschodniej stronie granicy, a tym samym do obniżenia poziomu Prypeci w dolnej części jej polskiego biegu. W efekcie, dolny bieg Lwy i Stwigi wpadających do Prypeci na północ od projektowanego rezerwatu, pozostałby trwale zabagniony, co zabezpieczyłoby niezmienność stosunków hydrologicznych w puszczy olchowej. Z kolei tereny położone na południe od rezerwatu, choć leżały na tyle wysoko, że można je było łatwo odwodnić, to jednak były to torfowiska wyżynne i przejściowe o znikomej wartości rolniczej. Wzdłuż południowo-zachodnich obrzeży tego obszaru projektowano jedynie kanał spławny łączący zagłębie granitowe w Klesowie z centralnymi obszarami Polesia ${ }^{54}$ (Ryc. 2).

Teren projektowanego rezerwatu był bardzo słabo zaludniony. Od czasów prehistorycznych, z uwagi właśnie na nieurodzajność torfowisk wyżynnych, bagna te opierały się próbom osadnictwa. Ziemie ten wchodziły w skład ordynacji Dawidgródeckiej należącej do księcia Karola Mikołaja Radziwiłła, który traktował je głównie jako tereny łowieckie. W latach trzydziestych XX w. tamtejsze lasy były ważną ostoją łosia i rysia, a nieprzełowione rzeki i jeziora obfitowały w ryby oraz ptactwo wodne. Tereny nad Lwą zasadniczo

52 Ibid.

53 W swoim raporcie Kulczyński nie podał dokładnej powierzchni projektowanego rezerwatu, stwierdzając jedynie, że „park natury obejmujący np. 100,000 ha nie da się pomyśleć” na torfowiskach nizinnych nadających się do zagospodarowania rolniczego. Taką właśnie powierzchnię zdaje się wskazywać obmiar przeprowadzony przez autora po nałożeniu granic parku na współczesną mapę Polesia. Niektóre z ówczesnych gazet mylnie określały jego powierzchnię na 200 tysięcy hektarów (zob. m.in. „Kurier Nowogródzki” 2.10.1934, s. 4). Niektóre współczesne opracowania podają również inne wartości wahające się od 100 do 200 tysięcy hektarów, nie opierając się jednak na żadnych źródłach.

54 Ibid 
ominęła też Zachodnia Ekspedycja generała Żylińskiego, a nieliczne wykonane przez nią kanały dawno uległy zniszczeniu. Z obserwacji Kulczyńskiego wynikało, że procesy zabagnienia i zatorfienia były tam $w$ toku, co pozwalało badać zjawiska przyrodnicze, które gdzie indziej w wyniku wcześniejszych robót melioracyjnych zostały zahamowane ${ }^{55}$. Teren projektowanego rezerwatu był pod tym względem jedynym na Polesiu i jednym z ostatnich w Europie ${ }^{56}$.

Nie wiadomo, kiedy i w jakich słowach Kulczyński poinformował o swoim wyborze Szafera, ale gdy na wiosnę 1932 r. zaprosił przewodniczącego PROP na objazd wybranego terenu, ten gratulował mu sukcesu „w sprawie uratowania części Polesia od melioracji”57. Do objazdu doszło latem, a o wyborze tej lokalizacji niewątpliwie poinformowany został Próchnik, który już na początku sierpnia prosił Szafera o przygotowanie artykułu promującego ideę powołania poleskiego parku natury właśnie w tym miejscu ${ }^{58}$.

Podczas wycieczki Szafer spotkał się z Radziwiłłem. Z krótkiej rozmowy odniósł wrażenie, że był on „wielkim miłośnikiem przyrody poleskiej” i że doceniał znaczenie „naukowe i krajoznawcze" takiego rezerwatu ${ }^{59}$. Na początku września Szafer skontaktował się z Jerzym Sękowskim, dyrektorem Ordynacji, prosząc o mapy, dane na temat gospodarki leśnej, informacje o liczbie i rozmieszczeniu zwierząt oraz fotografie potrzebne do pracy nad artykułem. Skorzystał wtedy z okazji, by jeszcze raz zapewnić Radziwiłła, że projekt rezerwatu powstanie w ścisłym porozumieniu z nim i w ten sposób, aby realizacja była „korzystną nie tylko dla idei ochrony przyrody, ale również i dla właściciela”. Szafer deklarował, że nie może być mowy o „jakiejkolwiek niespodziance, która postawiłaby Księcia przed jakimiś faktami dokonanymi, niepożądanymi dla Niego” i zaręczał o swojej „względem Niego lojalności"60.

Ta wystudiowana uniżoność na nic się jednak Szaferowi nie zdała. Odpowiedź, jaka po trzech tygodniach nadeszła z majątku Radziwiłłów w Mańkiewiczach nie była obiecująca. Sękowski pisał: „Książę Ordynat nie przychyla się do planu utworzenia rezerwatu, że tak się wyrażę oficjalnego, pragnąc zachować tereny te w swoim ręku, jako rezerwat prywatny". Radziwiłł najwyraźniej nie chciał nagłaśniać swojej decyzji, toteż przez zarządcę majątku prosił Szafera „o przyjęcie tego, jako wiadomości do osobistego użytku"61. Przewodniczący PROP bynajmniej nie czuł się zobligowany do zachowania dyskrecji i o stosunku ordynata do koncepcji parku natury niezwłocznie poinformował Próchnika. Odmowa (a Radziwiłł odmówił nawet udostępnienia materiałów do artykułu) jedynie utwierdziła Szafera w przekonaniu o potrzebie napisania tekstu, który ordynację Dawidgródecką wskazywałby jako najwłaściwszą lokalizacją rezerwatu².

Na praktycznie bezodpływowym obszarze Bagien Zaolmańskich Kulczyński zaobserwował proces obumierania lasów sosnowych na torfowiskach wysokich. Zob. S. Kulczyński, Torfowiska Polesia, t. 1, Kraków 1939, s. 325.

AN, sygn. 48 Kulczyński do Szafera, 4.10.1932 r.

57 AN, sygn. 48 Szafer do Kulczyńskiego, 1.04.1932 r.

58 AN, sygn. 48 Próchnik do Szafera, 10.08.1932 $r$.

59 AN, sygn. 48 Szafer do Sękowskiego, 5.09.1932 r.

60 Ibid..

61 AN, sygn. 48 Sękowski do Szafera, 22.09.1932 $r$.

62 AN, sygn. 48 Szafer do Próchnika, 4.10 .1932 r. Szafer był znany z bezkompromisowości. Kiedy w 1936 r. Minister Wyznań Religijnych i Oświecenia Publicznego usiłował wyegzekwować od pracowników jego biura punktualne rozpoczynanie pracy, Szafer odpisał: „o ile Pan Minister nie zwolni mnie od tych niemożliwych dla mnie warunków, proszę o przyjęcie mojej rezygnacji". Zob. Archiwum Akt Nowych w Warszawie [AAN], Zesp. Ministerstwa Wyznań Religijnych i Oświecenia Publicznego, sygn. 5990, k. 50 Szafer do MWRiOP, 4.07.1936 r. 


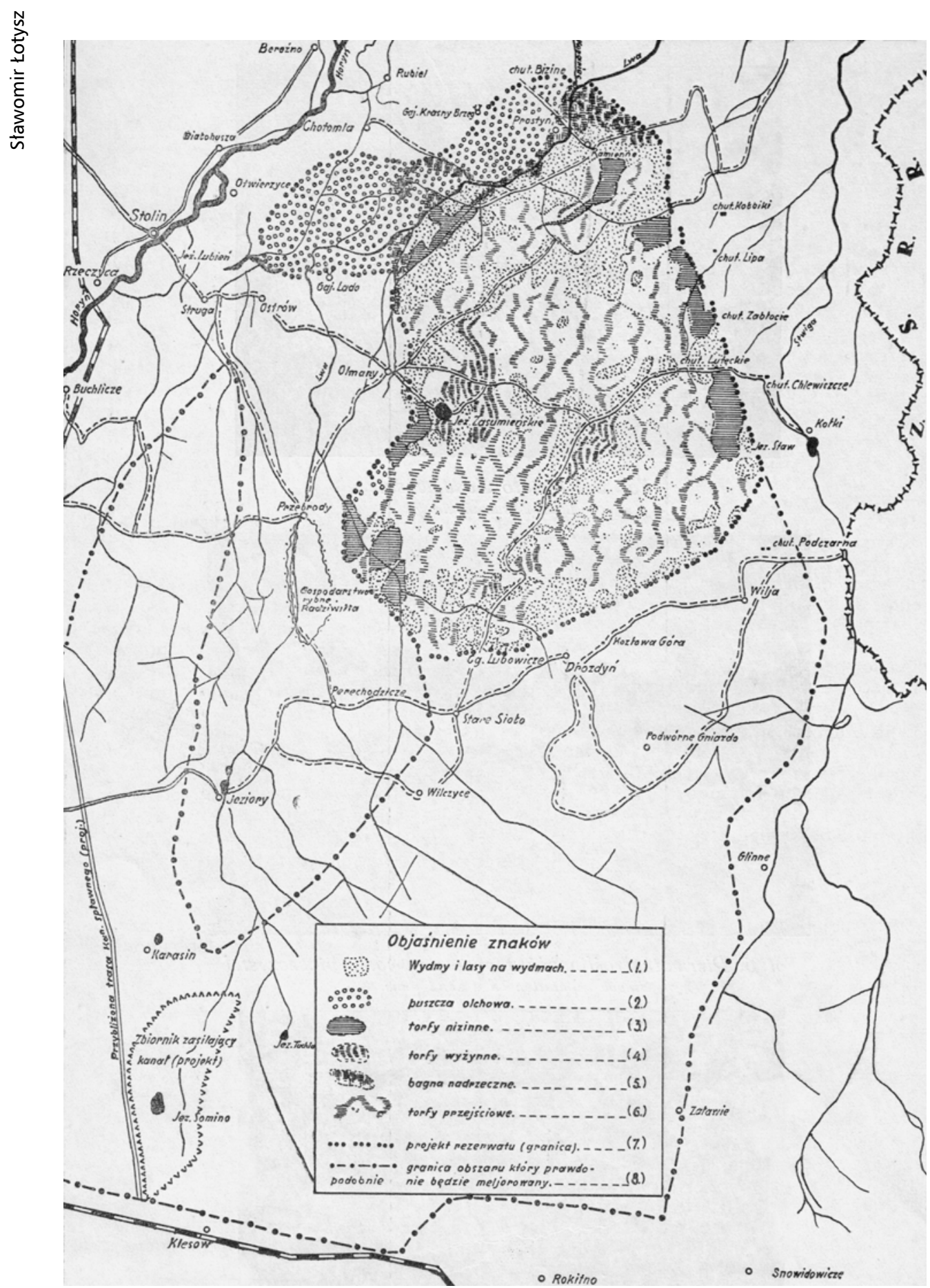

Ryc. 2. Poleski park natury według Stanisława Kulczyńskiego (Źródło: W. Szafer, Ochrona przyrody na Polesiu, [w:] Postępy prac przy Melioracji Polesia, Brześć nad Bugiem 1933, s. 138). 
W planach Próchnika artykuł ten miał duże znaczenie propagandowe. Miała to być swego rodzaju „odezwa do społeczeństwa i Rządu w sprawie tak szlachetnej i ważnej, jak ochrona poleskiej przyrody"63, toteż zachęcał Szafera, by mimo braku materiałów przygotował tekst jak najszybciej. Miał się ukazać w wydawnictwie zbiorowym podsumowującym cztery lata działalności badawczej Biura ${ }^{64}$. Największą trudność stanowił brak dokładnej mapy. Wprawdzie w ramach zakrojonych na szeroką skalę prac kartograficznych na Polesiu stosowano metodę aerofotogrametryczną, ale w pasie nadgranicznym na wschód od Horynia zdjęć lotniczych nie wykonywano. Próchnik uważał, że w artykule o charakterze programowym granice parku mogły być wykreślone w oparciu o mapę nieużytków torfowych opracowaną przez Kulczyńskiego. Nie było też potrzeby podawać precyzyjnych danych na temat liczebności zwierząt. Próchnik zdawał się nie przejmować brakiem woli współpracy ze strony Radziwiłła. Namawiał Szafera, by swoje następne wakacje zechciał spędzić na terenie „przyszłego Parku”, jak gdyby nie przewidywał żadnych komplikacji w przeprowadzeniu całego planu.

Niedługo później ustalenia te straciły jednak na aktualności. Wiosną 1933 r. do siedziby Biura wkroczyli inspektorzy ministerstwa komunikacji (któremu BPMP podlegało po rozwiązaniu rok wcześniej resortu robót publicznych). Inspekcję przeprowadzono na wniosek wojewody poleskiego Wacława Kostek-Biernackiego zaniepokojonego doniesieniami o nieprawidłowościach w funkcjonowaniu tej instytucji. Wniosek wojewody trafił na podatny grunt, bowiem służby kontrwywiadowcze obserwowały niektórych pracowników Biura już od 1929 r. z powodu podejrzeń o kontakty z agentami sowieckimi. W wyniku kontroli ujawniono nieprawidłowości w wydatkach oraz niedostateczny nadzór nad stanowiącymi tajemnicę państwową zdjęciami lotniczymi używanymi w pracach kartograficznych. Próchnika oraz dwóch innych pracowników Biura oskarżono o wyłudzenie nienależnych diet za podróże służbowe oraz niedbalstwo urzędnicze. Po kilku rozprawach w sądach różnych instancji Próchnika ostatecznie uniewinniono, ale ten przedłużający się sądowy spektakl nie tylko zrujnował jego reputację, lecz także doprowadził do zmniejszenia społecznego zainteresowania ideą melioracji Polesia ${ }^{65}$. W kwietniu 1934 r. BPMP zostało rozwiązane, a jego pracownicy, majątek i obowiązki zostały przejęte przez ministerstwo rolnictwa i reform rolnych (MRiRR) ${ }^{66}$. W 1937 r., w wyniku zmiany struktur organizacyjnych w tym resorcie wszelkie pozostałości specjalnej komórki zajmującej się melioracją Polesia przestały ostatecznie istnieć.

W tym czasie zmieniła się również koncepcja zagospodarowania poleskich bagien. Wizję wielkiej, prowadzonej „z rozmachem” i centralnie zarządzanej inwestycji zastąpił pogląd, że prace melioracyjne można, a w zasadzie należy, prowadzić etapami w zlewniach

63 AN, sygn. 48 Próchnik do Szafera, 7.10.1932 r.

64 Zanim Postępy prac przy melioracji Polesia ukazały się nakładem BPMP na początku 1933 r., Szafer zaczął propagować ideę Poleskiego Parku Natury nad Lwą m.in. na łamach „Ochrony Przyrody” (t. 12, 1932, s. 167). Przedruk skróconej wersji artykułu z Postępów ukazał się na łamach niedzielnych dodatków kulturalno-literackich „Dziennika Wileńskiego” i „Głosu Narodu” 15.10.1933 r.

65 Po wojnie Próchnik wykorzystał fakt oskarżenia, procesu i czasowego uwięzienia do budowy swojego wizerunku jako działacza komunistycznego i wielkiego przyjaciela Związku Radzieckiego. Według Polskiego Słownika Biograficznego aresztowany został za działalność komunistyczną i zarzut zdrady tajemnicy państwowej stanowił „wyraźną intrygę polityczną”, choć przyznanie się Próchnika do pobrania diet widnieje w zachowanych protokołach z jego przesłuchań. Zob. K. Dunin-Wąsowicz, Pruchnik Józef, [w:] Polski Słownik Biograficzny, t. 28, Wrocław 1984, s. 574-576.

66 MRiRR powstało w 1932 r. z połączenia ministerstwa rolnictwa oraz resortu reform rolnych. 
poszczególnych rzek, stanowiących niezależne od sobie systemy hydrologiczne. Wciąż pozostawiało to otwartą drogę do utworzenia poleskiego parku natury, a nawet współgrało z przyjętym przez Kulczyńskiego założeniem; przecież dorzecze Lwy i Stwigi było takim właśnie zamkniętym systemem. W 1938 r. „Rocznik Polityczny i Gospodarczy” wspomina o poleskim parku narodowym jako o przedsięwzięciu będącym wciąż w fazie projektu ${ }^{67}$.

Do wybuchu wojny parku w tym miejscu nie powołano, ale też i roboty melioracyjne, przed skutkami których rezerwat miał chronić poleską przyrodę ustały w tym czasie niemal zupełnie. U schyłku okresu międzywojennego większość lokalnych projektów melioracyjnych na Polesiu było negatywnie opiniowanych przez władze wojskowe. Chodzito o zachowanie dotychczasowego charakteru tego obszaru jako przeszkody terenowej w spodziewanym konflikcie ze wschodnim sąsiadem. Osuszenie całego Polesia na wielką skalę rozpoczęły dopiero władze radzieckie w latach pięćdziesiątych XX w. Wtedy też wróciła przedwojenna koncepcja utworzenia parku natury, który pozwoliłby zachować pewne fragmenty poleskiego krajobrazu. Początkowo wszelkie próby powołania takiego rezerwatu były skutecznie blokowane przez przedstawicieli przemysłu leśnego, niechętnego jakimkolwiek ograniczeniom możliwości korzystania z poleskich zasobów drzewnych ${ }^{68}$. Dopiero w 1969 r. został powołany Nacyjanaĺny park „Prypiacki” (Park Narodowy „Prypecki") o powierzchni przeszło 60 tysięcy hektarów ${ }^{69}$.

Marzenie Kulczyńskiego, aby objąć ochroną obszar bagien pomiędzy Lwą a Stwigą, przynajmniej częściowo, spełniło się dopiero po rozpadzie Związku Radzieckiego. W 1998 r. władze białoruskie utworzyły w tym samym miejscu rezerwat krajobrazowy „Błota Olmańskie" o powierzchni blisko 95 tysięcy hektarów ${ }^{70}$. Bagna te zostały wpisane na listę konwencji ramsarskiej z 1971 r., która obejmuje tereny wodno-błotne o szczególnym znaczeniu dla biosfery. Dziś połowę obszaru zajmują lasy, głównie sosnowe, ale na wzniesieniach zachowały się niewielkie kompleksy dębowe i grabowe, a w dolinie Lwy - resztki puszczy olchowej, która tak oczarowała Kulczyńskiego. Po łosiach i rysiach nie pozostało śladu, ale na terenie rezerwatu doliczono się 192 gatunków kręgowców lądowych, z czego 27 figuruje w białoruskiej „czerwonej księdze” gatunków zagrożonych. Fakt, że na tym terenie zachowało się aż tyle „osobliwości” natury jest o tyle szczególny, że w latach sześćdziesiątych funkcjonował tam poligon wojskowy oraz baza lotnictwa strategicznego ${ }^{71}$.

Powołanie rezerwatu krajobrazowego bynajmniej nie zapobiegło dalszej degradacji tutejszych bagien. W końcu 2018 r. przez północną część obszaru chronionego wybudowano 14kilometrową drogę gruntową ${ }^{72}$. Inwestycję finansowało ministerstwo leśnictwa tłumacząc to względami ekonomicznymi (łatwiejszy wywóz pozyskanego drewna) oraz troską o bezpieczeństwo lasów (dostęp dla wozów strażacki w przypadku pożaru). Na odcinku biegnącym

67 Rocznik Polityczny i Gospodarczy, s. 581.

68 S.A. Tretyak, op. cit., s. 329.

69 Ibid., s. 333.

70 Respublikanskiy landshaftnyy zakaznik 'Ol'manskiye bolota', zapovednytur.by/oopt/zakazniki/landshaftnye/ olmanskiye.html [dostęp 21.09.2019].

71 Jak wynika z relacji świadków, teren nadal usłany jest niewybuchami pocisków rakietowych, które utknęły w bagnistym gruncie. W latach siedemdziesiątych, już po zamknięciu poligonu, zaobserwowano w tym rejonie podwyższony poziom zawartości promieniotwórczego izotopu cez-137, co skłoniło niektórych badaczy do postawienia hipotezy, że na poligonie dokonywano wybuchów jądrowych. Zob. K. Brown, Manual for Survival: A Chernobyl Guide to the Future, New York 2019 (e-book).

72 Cherez Ol'manskiye bolota prokladyvayut dorogu. Ekologi: Zachem?, nn.by/?c=ar\&i =211533\&lang=ru [dostęp 21.09.2019]. 
przez torfowisko drogę zbudowano na grobli usypanej z piasku wydobytego na wydmach, które Kulczyńskiego chciał chronić z uwagi na występującą na nich roślinność reliktową ${ }^{73}$.

\section{Podsumowanie}

Mimo że do powołania poleskiego parku natury w okresie międzywojennym ostatecznie nie doszło, to wysiłki obrońców środowiska naturalnego skupionych wokół Państwowej Rady Ochrony Przyrody, by zwrócić uwagę na potrzebę ochrony tamtejszej przyrody zakończyły się powodzeniem. Mimo początkowych tarć w relacjach pomiędzy kierownictwem Biura Projektu Melioracji Polesia a Państwową Radą Ochrony Przyrody, udało się osiągnąć porozumienie i zainicjować rzeczową współpracę. Obie strony okazały się bowiem otwarte na argumenty - obrońcy przyrody przekonali technokratów, że w wyniku rezygnacji z mało obiecującego pod względem rolniczym terenu ekonomiczna strona inwestycji nie ucierpi, a sami z kolei przyjęli pogląd, że największym zagrożeniem dla środowiska naturalnego na Polesiu była trzebież lasów, a temu można było zapobiec otwierając dla osadnictwa rolniczego tamtejsze mokradła.

Otwartą pozostaje kwestia, na ile faktyczne zawieszenie realizacji idei parku wynikało ze zmiany koncepcji zagospodarowania Polesia, a na ile spowodował to brak Próchnika, który przecież w prace nad powołaniem rezerwatu zaangażował cały swój autorytet. Nieuczciwym byłoby zarzucać mu brak wrażliwości na potrzeby ochrony środowiska. Choć początkowo nie wykazał się jej nadmiarem, to przecież zapewniał o niej Szafera „najuroczyściej". Co więcej, gdy nieporozumienia pomiędzy nimi zostały wyjaśnione, wychodził z licznymi inicjatywami zmierzającymi w kierunku lepszej ochrony poleskiego krajobrazu, jak chociażby poleceniem katalogowania głazów narzutowych, wydanym podległym mu służbom technicznym ${ }^{74}$. Owszem, to zaangażowanie mogło mieć jeszcze inne tło. Próchnikowi niejednokrotnie zarzucano dyletantyzm i brak kompetencji, by kierować interdyscyplinarnymi badaniami na tak dużą skalę. Bliska współpraca z Szaferem i kierowaną przez niego Radą mogła z niego zdjąć odium dyletanta przynajmniej w tym zakresie. Jakiekolwiek były jego motywy, to wydaje się, że w swoim dążeniu do kompromisu w sprawie powołania poleskiego parku natury był nie mniej zdeterminowany niż Szafer.

Nie odrzucając tezy o roli osobistych poglądów Próchnika, zmiana polityki w sprawie parku natury na Polesiu po likwidacji Biura i przejęciu jego obowiązków przez ministerstwo rolnictwa mogła wynikać z przesłanek zasadniczych. Technokratyczna z definicji instytucja, jaką było podlegające ministerstwu robót publicznych BPMP, odpowiadając za techniczną stronę zagadnienia, mogła być, bardziej niż resort rolnictwa, otwarta na głosy

Jeszcze w trakcie trwania budowy próbę jej zablokowania podjęli działacze z organizacji Ochrona Ojczystych Ptaków (Achova ptušak Baćkaǔščyny). Żądanie zawieszenia inwestycji i ponownego zbadania jej wpływu na środowisko skierowano do Prokuratora Generalnego, jednak próba zapobieżenia dalszej dewastacji przyrody w rezerwacie zakończyła się niepowodzeniem. Jeden z działaczy Strażnicy, Andriej Abramczuk, przypomniał wówczas polskie plany utworzenia na tym terenie parku natury. W wywiadzie udzielonym na placu budowy reporterom portalu internetowego Nasza Niwa narzekał na bezczynność lokalnej społeczności: „W Polsce już byłyby tu namioty [protestujących]" - mówi zapominając najwyraźniej, że taka forma walki o środowisko nie zawsze sprawdza się nawet w krajach demokratycznych, a co dopiero w takich, w których władza nie liczy się z głosem obywateli. Zob. ibid.

74 Sprawozdanie z 53-ego posiedzenia, s. 149. 
różnych podmiotów, których dotyczyła planowana inwestycja, a zatem nie tylko środowisk gospodarczych, lecz także obrońców przyrody. MRiRR, jako organ realizujący określoną politykę rolną, samo będące de facto jednym z zaangażowanych podmiotów, było najbardziej zainteresowane maksymalizacją efektywności planowanej na Polesiu akcji melioracyjnej, a przeznaczenie znacznego obszaru na park natury tę efektywność zmniejszało. W tym okresie zaczęły pojawiać się głosy kwestionujące zasadność uznawania torfów wyżynnych za nienadające się pod kulturę rolną, a przecież właśnie to założenie, zgodnie akceptowane przez Kulczyńskiego, Próchnika i Szafera legło u podstaw decyzji o wyznaczeniu poleskiego parku natury nad Lwą. Podważenie tej zasady otwierało drogę do rewizji kompromisu wypracowanego przez Biuro i Radę, a tym samym do definitywnej rezygnacji z powołania rezerwatu, przynajmniej tak wielkiego i w tej lokalizacji. Wybuch drugiej wojny światowej i utrata polskiej suwerenności nad ziemiami wschodnimi już na zawsze pozostawiły tę kwestię wyłącznie w sferze domysłów.

\section{Bibliografia}

\section{Źródła archiwalne}

Archiwum Akt Nowych w Warszawie [AAN], Zespół Ministerstwa Wyznań Religijnych i Oświecenia Publicznego.

Archiwum Instytutu Hoovera [AlH], Zespół Ministerstwa Spraw Zagranicznych.

Archiwum Nauki Polskiej Akademii Nauk i Polskiej Akademii Umiejętności [AN], Zespół Państwowej Rady Ochrony Przyrody.

\section{Źródła drukowane}

Sprawozdanie z 53-ego posiedzenia Wydziału Państwowej Rady Ochrony Przyrody, „Ochrona Przyrody” 1931, t. 11, s. 147-154.

\section{Źródła prasowe}

"Czasopismo Techniczne":

Konderla A., Polesie. Studium krytyczne do projektu melioracji Polesia, cz. 2, „Czasopismo Techniczne" t. 51, 1933, nr 23, s. 359-367.

Próchnik J., Szkice techniczne z Rosji, Ukrainy i Białorusi Sowieckiej, „Czasopismo Techniczne" t. 49, 1931, nr 13, s. 223-227.

Próchnik J., Wycieczka naukowa do Estonii, Finlandii i Szwecji, „Czasopismo Techniczne” t. 47, 1929, nr 6, s. 87-93; nr 7, s. 99-105.

„Ochrona Przyrody":

Kulczyński S., Park natury na Polesiu i jego stosunek do planu melioracji, „Ochrona Przyrody" t. 10, 1930, s. 45-53.

Macko S., Roślinność projektowanych rezerwatów na Wołyniu, „Ochrona Przyrody” t. 17, 1937, s. 135.

Szafer W., Rozszerzenie rezerwatu bobrowego nad Żegulanką, "Ochrona Przyrody” t. 12, 1932, s. 167.

Szafer W., Uwagi o celach i organizacji badań naukowych w polskich parkach natury, „Ochrona Przyrody" t. 3, 1922, s. 10.

„Kurier Nowogródzki" 2.10.1934, s. 4. 


\section{Literatura przedmiotu}

Brown K., Manual for Survival: A Chernobyl Guide to the Future, New York 2019.

Kulczyński S., Rzut oka na problem bagienno-torfowy Polesia, [w:] Postęp prac przy melioracji Polesia, Brześć nad Bugiem 1933, s. 61-65.

Kulczyński S., Torfowiska Polesia, t. 1, Kraków 1939.

Łotysz S., „Gdyby zamiast Rosji było morze..." Techniczne i polityczne aspekty odwodnienia Polesia w II Rzeczypospolitej Polskiej, [w:] Rok 1918. Odrodzona Polska i sowiecka Rosja w nowej Europie, t. 1, red. L. Zasztowt i J. Szumski, Warszawa, s. 435-450.

Łotysz S., Władysław Szafer i Józef Próchnik w debacie o przyszłości poleskiej przyrody, „Analecta: Studia i Materiały z Dziejów Nauki” 2019, nr 1, s. 189-211.

Rocznik Polityczny i Gospodarczy, Warszawa 1938.

Szafer W., Ochrona przyrody na Polesiu, [w:] Postępy prac przy Melioracji Polesia, Brześć nad Bugiem 1933, s. 133-139.

Szymkiewicz D., Ilościowa charakterystyka sprawności gospodarki wodnej u roślin, [w:] Postępy prac przy melioracji Polesia, Brześć nad Bugiem 1933, s. 113-116.

Szymkiewicz D. i Świętochowski B., Oznaczanie potrzeb nawozowych torfów poleskich metodą wazonową, [w:] Postępy prac przy melioracji Polesia, Brześć nad Bugiem 1933 , s. 123-127.

Szymkiewicz D., Uwagi w sprawie rzekomo grożącego przesunięcia Polesia, [w:] Postępy prac przy melioracji Polesia, Brześć nad Bugiem 1933, s. 117-121.

Tretyak S.A., Kraj zapaviedny, [w:] J.M. Bochan i in., Bielarus praz pryzmu rehijanalnaj historyi: Prypiackaje Paliessie, Mińsk 2016, s. 325-380.

\section{Strony internetowe}

Cherez Ol'manskiye bolota prokladyvayut dorogu. Ekologi: Zachem?, nn.by/?c=ar\&i$=211533$ \&lang=ru [dostęp 21.09.2019].

Respublikanskiy landshaftnyy zakaznik 'Ol'manskiye bolota', zapovednytur.by/oopt/zakazniki/landshaftnye/olmanskiye.html [dostęp 21.09.2019].

\section{Finansowanie}

Praca powstała w wyniku realizacji projektu badawczego nr 2015/19/B/HS3/03553 finansowanego ze środków Narodowego Centrum Nauki.

dr hab. Sławomir Łotysz jest historykiem techniki zatrudnionym w Instytucie Historii Nauki im. L. i A. Birkenmajerów PAN na stanowisku profesora. Zajmuje się dziejami wynalazczości, a także zagadnieniami transferu i recepcji idei technicznych w powojennej Europie oraz historią środowiskową Polski. W kadencji 2017-2021 pełni funkcję przewodniczącego Międzynarodowego Komitetu Historii Techniki (ICOHTEC). e-mail: s.lotysz@gmail.com

Data zgłoszenia artykułu: 12 listopada 2019

Data przyjęcia do druku: 7 stycznia 2020 